\title{
Membangun Sistem Informasi Praktek Dokter
}

\author{
Nurmi \\ Program Studi Pendidikan Informatika STKIP PGRI Sumbar \\ Jl. Gunung Pangilun Padang \\ olmiinu@yahoo.com
}

http://dx.doi.org/10.22202/jei.2014.v1i1.1429

\begin{abstract}
ABSTRAK
Pengolahan data pasien pada Praktek Dokter pada umumnya masih dilakukan secara manual dan berulang-ulang dengan menggunakan Microsoft Office Word dan Excel. Informasi yang dihasilkan sering tidak tepat waktu dan kurang akurat. Dengan sistem manual Staf administrasi mengalami kesulitan dalam mencari kartu pasien yang disimpan dalam bentuk dokumen, sering terjadi penggandaan pencatatan data pasien, karena staf administrasi harus mencatat data pasien dan sekaligus melayani pasien yang berobat. Dari uraian di atas setelah observasi dan dianalisis dari beberapa tempat praktek maka perlu dirancang dan dibangun sitem informasi untuk pengolahan data pasien tersebut. Hasil analisis dan perancangan ini dapat dituangkan kedalam suatu program, dengan membangun sistem informasi praktek dokter. Berdasarkan pengamatan yang dilakukan pada tempat praktek tersebut sistem manual kurang layak lagi digunakan karena tidak seimbangnya jumlah staf yang melayani dengan jumlah Pasien yang dating berobat dalam waktu lebih kurang 4 jam yaitu dimulai dari jam 17.00 sampai dengan 21.00 WIB. Perancangan sistem informasi ini diharapkan dapat mengoptimalkan pemakai komputer yang sudah dimiliki pada tempat praktek tersebut dan dapat membantu pekerjaan staf administrasi dalam pengolahan data pasien, sehingga sistem informasi ini dapat meningkatan pelayanan, kinerja, kualitas informasi, efesiensi dan nilai ekonomis suatu sistem
\end{abstract}

Kata Kunci : Sistem Informasi, Praktek Dokter

\section{PENDAHULUAN}

Praktek Dokter melayani kesehatan masyarakat yang ada di lokasi tempat dokter membuka prakter yang bertanggung jawab dalam bidang kesehatan di wilayah kerjanya. Pelayanan prakter dokter dituntut untuk dapat memberikan pelayanan dan pembinaan kepada masyarakat melalui programprogram pokok kesehatan sesuai dengan spesialis yang dimiliki oleh dokter tersebut. Praktek dokter dapat berupa prakter dokter umum dan spesialis serta prakter dokter gigi.

Secara umum sistem pelayanan praktek dokter adalah sama yaitu sataf administrasi melayani pasien. Staf Administrasi melakukan pencatatan administrasi pasien dan mengolah data pasien yang berobat ke tempat praktek tersebut. Dokter yang memeriksa pasien sekaligus bertanggung jawab mengelola tempat praktek tersebut. Dari beberapa tempat praktek dokter yang diamati pasien yang datang menemui staf administrasi untuk pencatatan pendaftaran, setelah itu pasien akan menerima Kartu Pasien yang akan digunakan untuk berulang berobat. Pasien yang sudah menerima Kartu Pasien dapat menunggu giliran dipanggil untuk diperiksa dokter, dari hasil pemeriksaan tersebut akan diperoleh laporan berupa, Daftar Pasien, Kartu Status Pasien, Laporan Pasien yang Berobat dan lain-lain.

\section{IDENTIFIKASI MASALAH}

Berdasarkan hasil pengamatan dan observasi langsung yang dilakukan pada beberapa praktek dokter maka masalah yang dihadapi dapat diidentifikasi sebagai berikut :

1. Pengolahan data pasien praktek dokter masih dilakukan secara manual dengan menggunakan Microsoft Office Word dan Excel.

2. Staf administrasi kesulitan dalam mencari kartu pasien dan kartu status pasien yang disimpan dalam bentuk dokumen karena belum tersedianya media penyimpanan berupa database. Sehingga memperlambat proses pencarian data yang berdampak pada kinerja pelayanan pasien

3. Membutuhkan waktu yang lama dalam pengolahan data pasien sehingga informasi yang dihasilkan kurang tepat waktu dan kurang akurat.

\section{Sistem Pengolahan Data Pasien}

Sistem pengolahan data pasien adalah rangkaian kegiatan yang merupakan suatu proses pendaftaran pasien pada staf administrasi untuk dicatat data pasien dan keluhan penyakit yang dirasakan, kemudian diberikan Kartu Pasien untuk berulang berobat, sambil menunggu antrian dipanggil dokter untuk dilakukan pemeriksaan. Setelah 
pasien diperiksa maka akan dicatat pada Kartu Status Pasien, dari uraian kegiatan tersebut maka sistem akan menghasilkan laporan berupa Daftar Pasien, Laporan Pasien yang Berobat dan lain-lain.

\section{Sistem Informasi Pengolahan Data Pasien}

Sistem informasi pengolahan data pasien adalah rangkaian kegiatan pendaftaran pasien pada praktek doker yang dikerjakan oleh program aplikasi. Sebelum program aplikasi dibuat, maka seorang analis harus membuat suatu rancangan sistem agar dapat dipahami secara rinci oleh programmer. Sistem informasi yang dibangun membutuhkan data berupa: data pasien, data keluhan penyakit dan data diagnosa. Data tersebut dientrikan ke sistem informasi melalui Form Entry Data kemudian diolah sehingga menghasilkan Kartu Pasien, Kartu Status Pasien, Daftar Pasien, Laporan Pasien yang Berobat dan lain-lain.

\section{ANALISIS DAN PERANCANGAN SISTEM}

\section{Pengertian Analisis Sistem}

Analisis Sistem merupakan penguraian dari suatu sistem informasi yang utuh kedalam bagian-bagian komponennya dengan maksud untuk mengindentifikasikan dan mengevaluasi permasalahan-permasalahan,

kesempatan-kesempatan, hambatanhambatan yang terjadi dan kebutuhankebutuhan yang diharapkan sehingga dapat diusulkan perbaikannya.

Tahap analisis sistem dilakukan setelah tahap perencanaan sistem dan sebelum tahap desain sistem. Tahap analisis merupakan tahap yang kritis dan sangat penting, karena kesalahan didalam tahap ini akan menyebabkan juga kesalahan di tahap selanjutnya.

2. Pengertian Perancangan Sistem

Perancangan sistem dapat didefenisikan sebagai penggambaran, perencanaan dan pembuatan sketsa atau pengaturan dari berbagai elemen yang terpisah kedalam satu kesatuan yang utuh dan berfungsi.

Perancangan (desain) sistem merupakan tahap setelah analisis dari siklus pengembangan sistem yaitu pendefinisian dari kebutuhan-kebutuhan fungsional dan persiapan untuk rancang bangun implementasi yaitu menggambarkan bagaimana suatu sistem dibentuk.

\section{ELEMEN KEBERHASILAN HASIL} RANCANGAN
Mengukur keberhasilan hasil perancangan sistem informasi dapat dilihat apabila sistem informasi sudah diterapkan terjadi peningkatan-peningkatan yang berhubungan dengan :

1. Kinerja (Performance) yaitu peningkatan hasil kerja sistem yang baru sehingga menjadi lebih efektif dalam pengolahan data asien.

2. Informasi (Information) terjadi peningkatan terhadap kualitas informasi yang disajikan, yaitu sistem informasi memberikan informasi yang berkualitas untuk pasien staf administrasi dan pimpinan parktek dokter tersebut.

3. Ekonomis (Economy) tercipta peningkatan terhadap manfaat-manfaat atau penurunan biaya operasiona yang terjadi dalam pengolahan data pasien.

4. Pengendalian (Control) menghasilkan peningkatan terhadap pengendalian untuk mendeteksi dan memperbaiki kesalahan-kesalahan serta kecurangan yang akan terjadi dalam pengolahan data pasien pada tempat praktek dokter tersebut.

5. Efisiensi (Efficiency) terjadi peningkatan terhadap efisiensi operasi, yaitu satu staf dapat melayani 20 pasien dalam waktu 4 jam praktek.

Efisiensi berbeda dengan ekonomis. Bila ekonomis berhubungan dengan jumlah sumber daya yang digunakan sedangkan efisiensi berhubungan dengan bagaimana sumber daya tersebut digunakan dengan pemborosan yang paling minimum. Eifisiensi dapat diukur dari outputnya dibagi dengan inputnya.

6. Pelayanan (Services) : meningkatan terhadap pelayanan yang diberikan oleh sistem, artinya informasi atau laporan tentang pasien kapanpun di butuhkan dapat dilayani oleh sistem dalam waktu yang cukup singkat bila dibandingkan dengan sistem manual.

\section{PROSES ANALISIS DAN PERANCANGAN SISTEM}

Proses analisis dan pengembangan sistem informasi pengolahan data pasien harus berpedoman kepada konsep System Development Life Cycle (SDLC). Konsep SDLC disebut juga dengan siklus hidup pengembangan sistem terdiri dari beberapa tahapan yaitu mulai dari perencanaan sampai sistem itu diterapkan, dioperasikan, dan dipelihara. Tahapan utama siklus hidup pengembangan sistem terdiri dari : perencanaan sistem, analisis sistem, 
perancangan sistem dan penerapan sistem dan perawatan sistem.

\section{PERANCANGAN SISTEM INFORMASI PENGOLAHAN DATA PASIENPADA PRAKTEK DOKTER}

Bentuk rancangan tersebutdapat berupa Analisis Sistem Informasi (ASI), dan Data Flow Diagram $(D F D)$.

\section{Aliran Sistem Informasi (ASI)}

ASI Membangun Sistem Informasi Praktek Dokter, dapat dilihat pada gambar berikut :

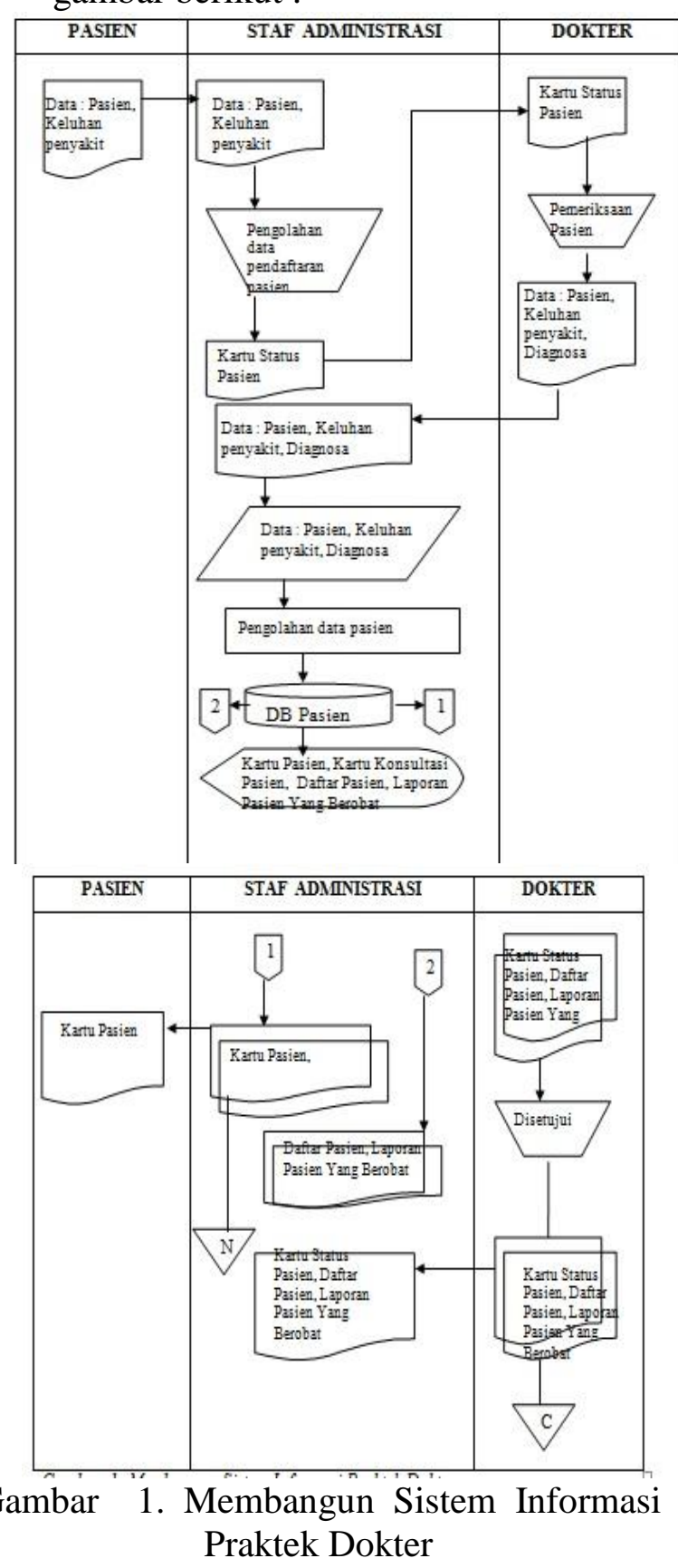

\section{Data Flow Diagram (DFD)}

DFD menjelaskan proses terbentuknya informasi dari program aplikasi yang digunakan. DFD Membangun Sistem Informasi Praktek Dokter dapat dilihat pada diuraikan sebagai berikut : a. Context Diagram : Membangun Sistem Informasi Praktek Dokter pada gambar berikut ini :

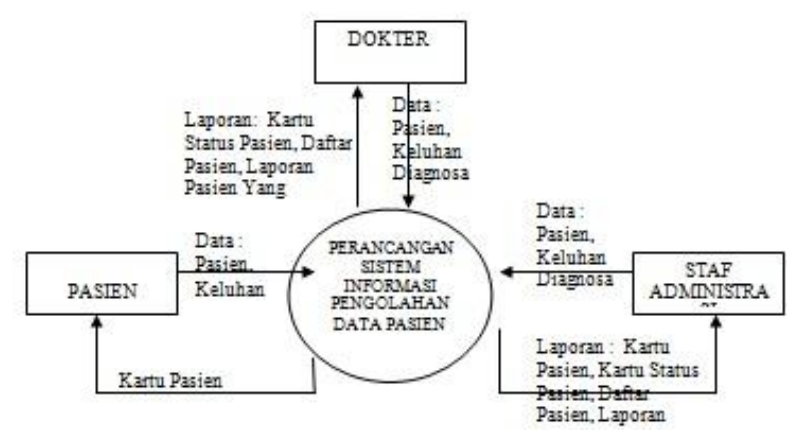

Gambar 2. Context Diagram Membangun Sistem Informasi Praktek Dokter

b. DFD Level Satu : Membangun Sistem Informasi Praktek Dokter dapat dilihat pada gambar berikut :

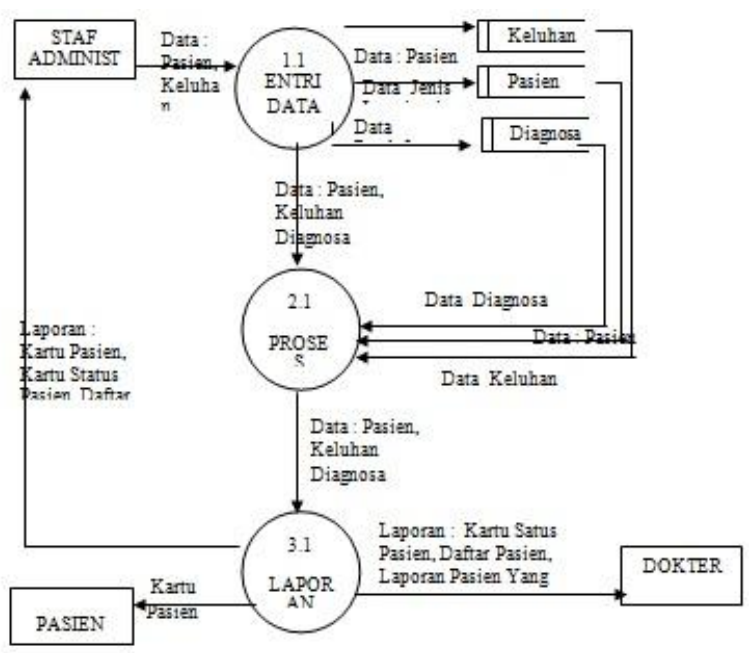

Gambar 3. DFD Level Satu : Membangun Sistem Informasi Pengolahan Praktek Dokter

\section{KESIMPULAN}

Berdasarkan urai di atas, untuk meningkatkan efisiensi dalam pengolahan data pasien yang dilakukan pada praktek dokter tersebut dapat disimpulkan sebagai berikut :

1. Sistem pengolahan data pada praktek dokter pada umumnya masih dilakukan secara manual dengan menggunakan Microsoft Office Word dan Excel. Sehingga informasi yang dihasilkan, sering kurang tepat waktu dan kurang akurat.

2. Sistem manual mengalami kesulitan bagi staf administrasi dalam mencari kartu dan kartu status pasien, dan sering 
terjadinya penggandaan dalam hal pencatatan data pasien, karena staf administrasi harus mencatat data pasien dan sekaligus melayani pasien yang berobat.

3. Untuk mengatasi masalah tersebut perlu membangun sistem informasi, dengan tujuan dapat mengatasi masalah yang terjadi pada praktek dokter dan membantu staf administrasi dalam mengolah data pasien dalam rentang waktu $17.00 \mathrm{~s} / \mathrm{d} 21.00$ WIB. Hal ini karena tidak seimbangnya jumlah staf yang melayani dengan jumlah Pasien yang datang berobat.

4. Sistem informasi dapat mengoptimalkan penggunaan komputer yang dimiliki oleh praktek dokter tersebut, sehingga menghasilkan suatu sistem yang berkualitas dan bernilai.

\section{DAFTAR PUSTAKA}

Al Bahra Bin Ladjamudin (2005), "Analisa dan Perancangan Sistem Informasi”, Graha Ilmu: Jakarta.

Azies,(2010), “SistemInformasi”,http://www .aziessite.blogspot.com diakses tanggal 4 Januari 2014.

Jogiyanto, HM,(2006), "Sistem Informasi Berbasis Komputer”,Andi Offset : Yogyakarta.

Kendall E, Kendall J,( 2007), “Analisis dan Perancangan Sistem”,PT Indeks : Klaten 